Ambiente \& Água - An Interdisciplinary Journal of Applied Science
ISSN 1980-993X - doi:10.4136/1980-993X
www.ambi-agua.net
E-mail: ambi.agua@gmail.com

\title{
Determination and evaluation of mercury concentration in fish in the São Francisco River Watershed, Brazil
}

\author{
ARTICLES doi:10.4136/ambi-agua.2647
}

Received: 13 Sep. 2020; Accepted: 26 Feb. 2021

\section{Marcos Vinícius Teles Gomes ${ }^{1}$; Carlos Alexandre Borges Garcia ${ }^{2 *(D D}$; Yoshimi Sato $^{3}$; Érica Araújo Mendes 4 iD; Mário Olindo Tallarico de Miranda ${ }^{5}$; Silvânio Silvério Lopes da Costa ${ }^{6}$}

\footnotetext{
${ }^{1}$ Departamento de Limnologia e Aquicultura. Companhia de Desenvolvimento dos Vales do São Francisco e do Parnaíba (CODEVASF), BR 101, Km 2, CEP: 57290-000, Porto Real do Colégio, Alagoas, Brazil. E-mail: marcos.teles@codevasf.gov.br

${ }^{2}$ Centro de Ciências Exatas e Tecnologia. Departamento de Quimíca. Universidade Federal de Sergipe (UFS), Avenida Marechal Rondon, s/n, CEP: 49100-000, São Cristóvão, SE, Brazil.

${ }^{3}$ Centro Integrado de Recursos Pesqueiros e Aquicultura. Companhia de Desenvolvimento dos Vales do São Francisco e do Parnaíba (CODEVASF), Avenida Geraldo Rodrigues dos Santos, s/n, CEP: 39205-000, Três Marias, MG, Brazil. E-mail: sato.codevasf@gmail.com

${ }^{4}$ Unidade de Desenvolvimento Territorial. Companhia de Desenvolvimento dos Vales do São Francisco e do Parnaíba (CODEVASF), Avenida Geraldo Ataíde, n 483, CEP: 39400-292, Montes Claros, MG, Brazil. E-mail: erica.mendes@codevasf.gov.br

${ }^{5}$ Superintendência Estadual de Minas Gerais. Instituto Brasileiro do Meio Ambiente e dos Recursos Naturais Renováveis (IBAMA), Avenida do Contorno, nº 8121, CEP: 30110-051, Belo Horizonte, MG, Brazil. E-mail: mario.tallarico@gmail.com

${ }^{6}$ Núcleo de Petróleo, Gás e Biocombustível (NUPEG). Universidade Federal de Sergipe (UFS), Avenida Marechal Rondon, s/n, CEP: 49100-000, São Cristóvão, SE, Brazil.

E-mail: silvanioslc@gmail.com

*Corresponding author. E-mail: cgarcia@ufs.br
}

\begin{abstract}
The objective of this work was to evaluate the bioaccumulation of mercury in 13 species of fish with different eating habits, captured in the Três Marias Reservoir, São Francisco Basin, from March 2012 to April 2013. The results obtained showed that the species with carnivorous eating habit presented the highest average concentrations of mercury in muscle, especially Serrasalmus brandtii (pirambeba) and Pygocentrus piraya (piranha), with concentrations of $0.4147 \pm 0.2744 \mu \mathrm{g} \mathrm{g}^{-1}$ and $0.17774 \pm 0.2980 \mu \mathrm{g} \mathrm{g}^{-1}$, respectively. Considering the average concentrations, all the species studied showed levels of mercury below the maximum limit of $0.5 \mu \mathrm{g} \mathrm{g}^{-1}$ in non-predatory fish and $1.0 \mu \mathrm{g} \mathrm{g}^{-1}$ in predatory fish, established by the Agência Nacional de Vigilância Sanitária. Taking each species into account, the minimum and maximum values of mercury in the muscular and hepatic tissues showed a wide dispersion. In $4 \%$ of the specimens of pirambeba and $7 \%$ of piranha, the contents of mercury in muscle exceeded the limit established by ANVISA for predatory fish, and therefore, were unfit for human consumption. The other species did not present muscle samples with $\mathrm{Hg}$ content above that established by law. Due to its carnivorous eating habit and its wide distribution in the São Francisco Basin, Serrasalmus brandtii can be considered a biomonitor, capable of bioaccumulating mercury, thus indicating the level of contamination in the aquatic environment in which it lives.
\end{abstract}

Keywords: fish, mercury, São Francisco River. 


\section{Concentração de mercúrio total em peixes do reservatório de Três Marias, Bacia do rio São Francisco}

\section{RESUMO}

Diante da toxicidade do mercúrio para o ser humano e para o meio ambiente, o objetivo deste trabalho foi avaliar a sua bioacumulação em 13 espécies de peixes com diferentes hábitos alimentares, capturados no reservatório de Três Marias, bacia do rio São Francisco, no período de março de 2012 a abril de 2013. Os resultados obtidos revelam que as espécies com hábito alimentar carnívoro apresentaram as maiores concentrações médias de mercúrio em músculo, com destaque para Serrasalmus brandtii (pirambeba) e Pygocentrus piraya (piranha), com concentrações de $0,4147 \pm 0,2744 \mu \mathrm{g} \mathrm{g} \mathrm{g}^{-1}$ e $0,1774 \pm 0,2980 \mu \mathrm{g} \mathrm{g}^{-1}$, respectivamente. Considerando as concentrações médias, todas as espécies estudadas apresentaram teores de mercúrio abaixo dos limites máximos de $0,5 \mu \mathrm{g} \mathrm{g}^{-1}$ em peixes não predadores e de $1,0 \mu \mathrm{g} \mathrm{g}^{-1}$ em peixes predadores, estabelecidos pela Agência Nacional de Vigilância Sanitária. Levando em conta cada espécie, os valores mínimos e máximos de mercúrio nos tecidos muscular e hepático demonstraram uma ampla dispersão. Em $4 \%$ dos espécimes de pirambeba e $7 \%$ de piranha, os teores de mercúrio em músculo ultrapassaram o limite estabelecido pela ANVISA para peixes predadores, e, portanto, sendo impróprios para o consumo humano. As demais espécies não apresentaram amostras de músculo com teor de $\mathrm{Hg}$ acima do estabelecido em lei. Devido ao seu hábito alimentar carnívoro e sua ampla distribuição na bacia do rio São Francisco, Serrasalmus brandtii pode ser considerada como biomonitor, capaz de bioacumular mercúrio, indicando, assim, o nível de contaminação desse metal no ambiente aquático em que vive.

Palavras-chave: mercúrio, peixe, rio São Francisco.

\section{INTRODUCTION}

Fish is an important part of a healthy human diet. Undefined fish of high quality proteins and other nutrients essential to the diet, are low in saturated fat and acidified omega- 3 fatty acids. A well-balanced diet that includes a variety of fish can contribute to heart health and the proper growth and development of children. Therefore, women and children in particular should include fish in their diets due to the many nutritional benefits.

Mercury $(\mathrm{Hg})$ toxicity to humans and the environment has been the subject of several studies (Miranda et al., 2007; WHO, 1990; Lee et al., 2010; Silva and Estanislau, 2015; Barragán et al., 2020; Assis et al. 2019). The best-known and cited case of mercury poisoning occurred more than six decades ago in the Japanese city of Minamata, where several people died and suffered from neurological symptoms associated with the consumption of fish and seafood contaminated with methylmercury (MeHg).

Mercury presents several chemical species, especially elemental mercury $\left(\mathrm{Hg}^{0}\right)$, found mainly in the form of gas, ionic mercury, in the oxidized forms of mercurous $\left(\mathrm{Hg}_{2}{ }^{2+}\right)$ and mercurial $\left(\mathrm{Hg}^{2+}\right)$ ions and methylated forms, methylmercury $\left(\mathrm{CH}_{3} \mathrm{Hg}^{+}\right)$and dimethylmercury $\left(\left(\mathrm{CH}_{3}\right)^{2} \mathrm{Hg}\right)$ ions (Miranda et al., 2007; Hina et al., 2021; Silva Oliveira et al., 2021). Formed by methylation of inorganic $\mathrm{Hg}$, methylmercury is considered the most toxic form, with neurotoxic action and teratogenic agents (WHO, 1990).

One of the most worrying types of pollution of aquatic and terrestrial systems is the result of the dumping of potentially toxic metals, which due to their increasing use in industries and other activities, led to the change in the natural geochemical cycle and, consequently, the greater dispersion in the environment. Among metals, mercury is considered to have the most toxic potential and the only one which has been proven to undergo biomagnification along the trophic chain, also suffering efficient organification to its most toxic form (methylmercury) in the 
aquatic environment (Barrocas and Wasserman, 1995). Due to its ability to remain for long periods in the tissues of organisms, the consumption of contaminated fish is the main route of human exposure to methylmercury (Bahia, 1997), since it can be found in high concentrations mainly in species of fish with carnivorous eating habits (Boening, 2000; Trasande et al., 2005).

In fish, the accumulation of metals occurs through absorption to the surface of the integument, breathing and eating habits. Size, eating habits, weight, age and length are some of the factors which are related to accumulation capacity. Bioaccumulation (bioconcentration) occurs by the direct accumulation of the chemical agent from water. The phenomenon of biomagnification is accumulation through feeding, with transfer of the contaminant from one trophic level to another (Sterling, 1994; Barron, 2003). Fish can be subject to both processes and be used as biomonitors for metals, indicating the level of contamination and bioavailability of these in the region in which they live, even with some relative mobility (Förstner and Wittmann, 1983; Clarkson, 1998).

The highest concentrations of mercury are generally found in fish of higher trophic level (Mason et al. 1995; Neumann and Ward, 1999; Dietz et al., 2000; Gilmour and Riedel, 2000; Bastos et al., 2006; Dorea et al., 2006) through biomagnification; almost $100 \%$ of the mercury which bioaccumulates in the tissue of predatory fish corresponds to methylmercury (USEPA, 2001). Consumption of these contaminated fish can result in the ingestion of high levels of this substance. Based on risk assessments and based on available data and research, several countries and International Organizations have established reference levels for daily or weekly mercury intake considered safe (or without appreciable risk to health), where reference intake levels for methylmercury exposure range from 0.7 to $2 \mu \mathrm{g}$ of $\mathrm{MeHg}$ per kilogram of body weight $\left(\mu \mathrm{gg}^{-1}\right)$ per week (WHO, 2008).

In Brazil, the National Health Surveillance Agency (ANVISA) (ANVISA, 2013), considering the risks of the consumption of mercury-contaminated fish and aiming to protect public health, has set a maximum limit of $0.5 \mu \mathrm{g} \mathrm{g}^{-1} \mathrm{Hg}$ in non-predatory fish and $1.0 \mu \mathrm{g} \mathrm{g}^{-1}$ in predatory fish. In the Amazon, several studies have used mercury concentrations in hair as a biomarker to evaluate human exposure to this contaminant, mainly due to the diet composed of high fish intake (Pinheiro et al., 2006; Lima et al., 2015; Costa Júnior et al., 2015; 2018; Silva et al., 2020; Zampieri et al., 2020).

Reports from Sweden and Canada suggest that methylmercury concentrations in fish may increase after the construction of artificial water reservoirs (WHO, 1990). According to Hecky et al. (1991), the formation of new large hydroelectric reservoirs in northern Canada was accompanied by increased concentrations of methylmercury in fish, previously associated only with industrial pollution. Terrestrial vegetation and organic soils of flooded areas provide an anoxic environment favorable to increased methylation of mercury, a predominantly microbial process that occurs in lakes (Gilmour and Henry, 1991).

In Lake Chapala, Mexico, the highest concentrations of mercury in fish samples were found in carp (mean of $0.87 \mu \mathrm{g} \mathrm{g}^{-1}$ ), where a study with 92 women from three communities along the lake, with ages ranging from 18 to 45 years, found that $27.2 \%$ of them had concentrations of mercury in their hair greater than $1 \mu \mathrm{g} \mathrm{g}^{-1}$ (Trasande et al., 2010).

In Canada, an environmental monitoring program was established to evaluate the physical and chemical aspects and changes associated with the development of the La Grande hydroelectric complex and verified that in the reservoirs studied after filling, the average mercury levels in all fish species increased by factors from two to eight compared to natural lakes. The maximum levels were reached in the period from 4 to 11 years after filling in nonpiscivore species ( 0.33 to $0.72 \mu \mathrm{g} \mathrm{g}^{-1}$ ) and from 9 to 14 years in piscivore species (1.65 to 4.66 $\left.\mu \mathrm{g} \mathrm{g}^{-1}\right)$, depending on the environment. The return to levels equivalent to those of natural lakes was generally completed after 10 to 20 years of filling in non-piscivore species, and after 20 to 30 years in piscivore species (Schetagne and Therrien, 2013). 
Given the toxicity of mercury to humans and the environment, this work evaluated bioaccumulation in 13 fish species with different eating habits (6 carnivores, 4 omnivores, 2 detritivorous and 1 herbivore), captured in the Três Marias Reservoir, Minas Gerais, Brazil, from March 2012 to April 2013. Total mercury concentrations were analyzed in tissue samples (liver and muscle), and the results were compared with biometric data (weight and length) to verify possible correlations. Total mercury concentrations in fish muscle were compared to the maximum tolerance limits of inorganic contaminants in food, established by ANVISA. These data will be of great importance, as they serve as base values for a future study of the possible impacts caused by the arrival of the mud from the rupture of the Brumadinho Dam.

\section{MATERIAL AND METHODS}

\subsection{Study area}

The Três Marias Reservoir is approximately 2700 meters long and has a maximum depth of 75 meters. When it reaches the maximum quota, the flooded area is $1,050 \mathrm{~km}^{2}$ and volume of 21 billion $\mathrm{m}^{3}$ (Britski et al., 1988). The reservoir (Figure 1) is located in the upper São Francisco River region, Minas Gerais, Brazil, and its flooded area is positioned between the $18^{\text {th }}$ and $19^{\text {th }}$ South parallels and the $44^{\circ}$ and $46^{\circ}$ West meridians. Its main tributaries are the rivers São Francisco, Paraopeba, São Vicente, Sucuriú, Indaiá, Extrema, Borrachudo and Boi, reaching the municipalities of Abaeté, Biquinhas, Felixlândia, Morada Nova de Minas, Paineiras, Pompéu, São Gonçalo do Abaeté and Três Marias.

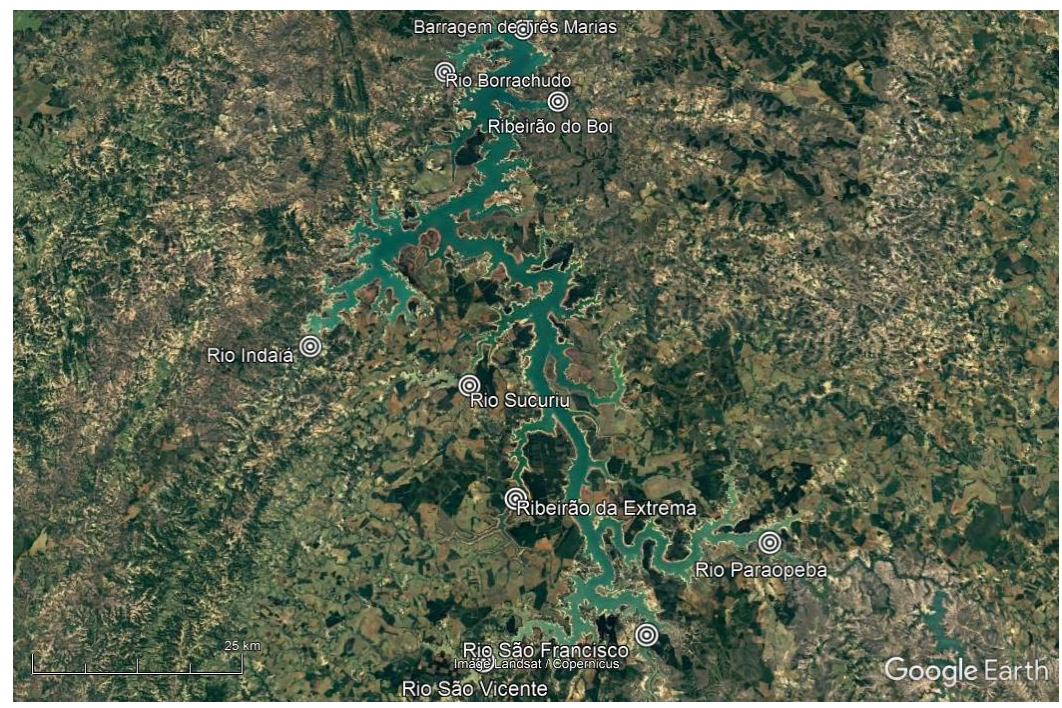

Figure 1. Map of the Três Marias Reservoir and its main tributary rivers.

\subsection{Sampling}

Fish were caught in the Três Marias Reservoir near the mouth of the Borrachudo, Indaiá and Paraopeba Rivers, using a set of gillnets with meshes of 3, 4, 5, 6, 7, 8, 10, 12, 14 and 16 $\mathrm{cm}$ (between opposite nodes). The nets were placed in the afternoon and removed in the morning of the next day, remaining in the water for approximately 14 hours. The specimens were identified using the identification keys contained in Britski et al. and in the Fishbase database (FISHBASE, 2019). After measurement of length and mass, samples of liver and muscle tissue (skinless and without flaking) were collected near the dorsal fin. The samples were then stored in polyethylene bottles and stored in a freezer until they were analyzed in the chemistry laboratory of the São Francisco Valley development company and Parnaíba (Codevasf), located in the municipality of Três Marias. 


\subsection{Analytical procedures}

The analysis method used to determine the total mercury concentration in the fish muscle and liver samples was based on thermal decomposition, amalgamation and detection by atomic absorption spectrometry, reaching a detection limit of $0.005 \mathrm{ng}$ of mercury. The DMA-80 equipment (Direct Mercury Analyser, Milestone) was used, with direct mercury analysis without the need for digestion or pretreatment of the sample, according to the USEPA 7473 method, recommended by the United States Environmental Protection Agency (USEPA, 2007).

\subsection{Data processing}

The statistical analysis of the data was performed by linear regression and the determination of the degree of correlation between the variables through Pearson's correlation coefficient, applying the Program BioEstat 5.0 for Windows. The charts with the average, minimum and maximum concentrations were elaborated with the Microsoft Office Excel 2010 software.

\section{RESULTS AND DISCUSSION}

Total mercury levels were analyzed in 311 specimens belonging to a group of 13 fish species caught in the Três Marias Reservoir (Figure 2), with different eating habits (6 carnivores, 4 omnivores, 2 detriivores and 1 herbivore). The concentrations were compared with biometric data and with the maximum $\mathrm{Hg}$ limits in fish for human consumption, stipulated by the National Health Surveillance Agency (ANVISA, 2013).

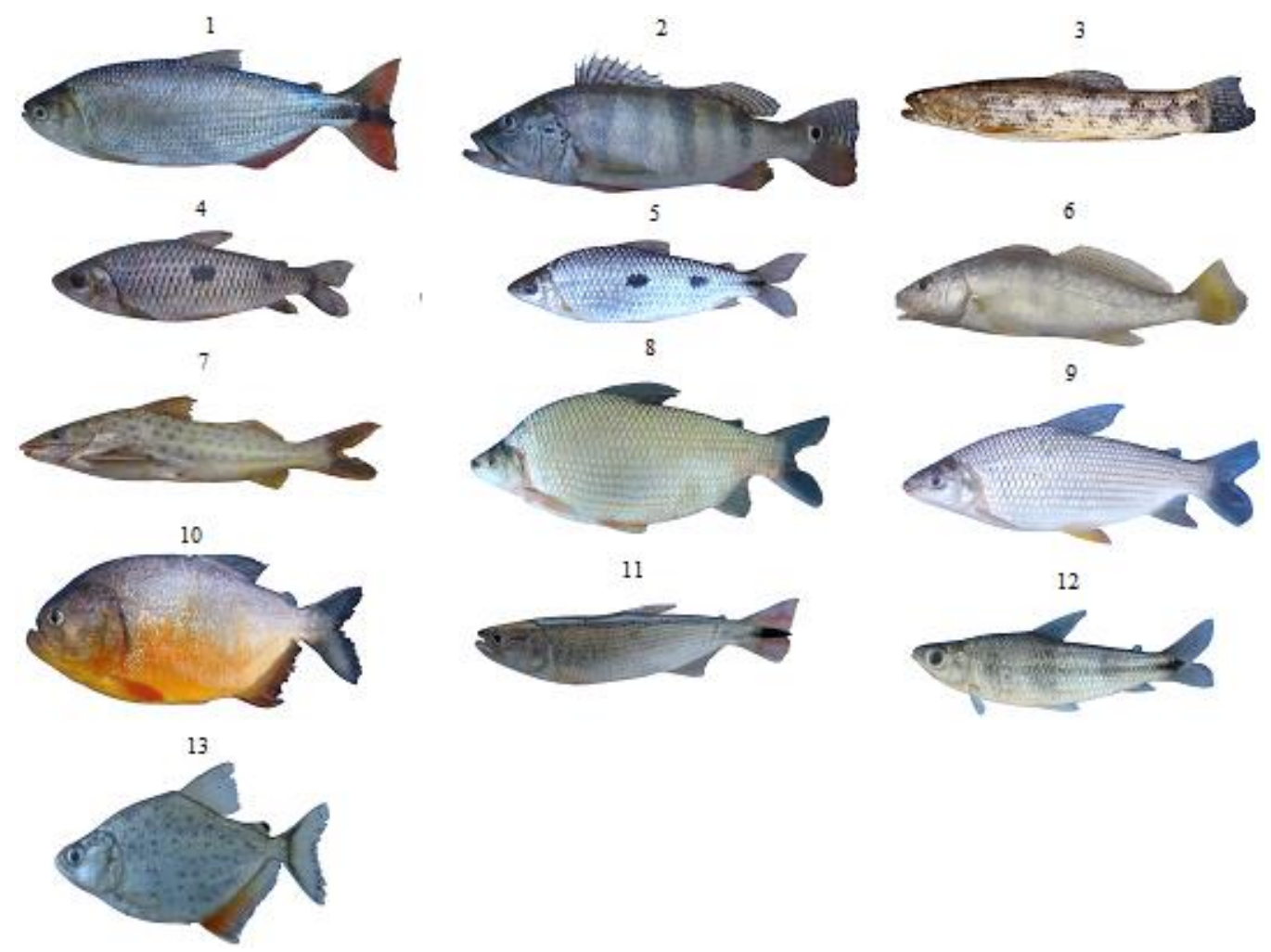

Figure 2. Fish species caught in the Três Marias Reservoir: 1- Brycon orthotaenia Günther, 1864; 2 - Cichla piquiti Kullander \& Ferreira, 2006; 3 - Hoplias intermedius (Günther, 1864); 4 - Leporinus piau Fowler, 1941; 5 - Leporinus reinhardti Lütken, 1875; 6 - Pachyurus francisci (Cuvier, 1830); 7 - Pimelodus maculatus Lacepède, 1803; 8 - Prochilodus argenteus Spix \& Agassiz, 1829; 9 - Prochilodus costatus Valenciennes, 1850; 10 - Pygocentrus piraya (Cuvier, 1819); 11 - Salminus hilarii Valenciennes, 1850; 12 -Schizodon knerii (Steindachner, 1875); and 13 - Serrasalmus brandtii Lütken, 1875. 
To certify the analytical method, mercury determinations were made in reference material composed of fish protein (DORM-3), with known $\mathrm{Hg}$ content $\left(0.382 \pm 0.060 \mu \mathrm{g} \mathrm{g}^{-1}\right)$ and prepared by the National Research Council Canada (NRC), where the recovery of mercury contents ranged from 92.3 to $107.1 \%$.

For species with the number of specimens greater than 12 , the correlation matrix was calculated, showing Pearson's correlation coefficients, which measures the degree of linear relationship between each pair of the following parameters: mercury concentration in muscle $(\mathrm{Hg}-\mathrm{M})$ and liver $(\mathrm{Hg}-\mathrm{F})$, total length $(\mathrm{CP})$ and body weight $(\mathrm{CP})$. Simple linear regression was also applied to examine the linear relationship between mercury concentrations in the muscle and liver of each species, obtaining the line which best represents the data.

The results obtained (Table 1) reveal that species with carnivorous eating habits presented the highest mean concentrations of mercury in muscle, which ranged from $0.0932 \mu \mathrm{g} \mathrm{g}^{-1}$ (Trairão) to $0.4147 \mu \mathrm{g} \mathrm{g}^{-1}$ (Pirambeba). In the other species, the means ranged from $0.0269 \mu \mathrm{g}$ $\mathrm{g}^{-1}$ (Curimatã pioa) to $0.0703 \mu \mathrm{g} \mathrm{g}{ }^{-1}$ (Piau gordura). In liver tissue, the highest mean concentrations of mercury were found in Corvina $\left(0.1916 \mu \mathrm{g} \mathrm{g}^{-1}\right)$, Pirambeba $\left(0.1872 \mu \mathrm{g} \mathrm{g}^{-1}\right)$ and Pacu curimatã $\left(0.1735 \mu \mathrm{g} \mathrm{g}^{-1}\right)$. The maximum levels of mercury in muscle and liver were found in the carnivorous species Pirambeba $\left(1.6303 \mu \mathrm{g} \mathrm{g}^{-1}\right.$ and $2.4335 \mu \mathrm{g} \mathrm{g}^{-1}$, respectively) and Piranha (1.2073 $\mu \mathrm{g} \mathrm{g}^{-1}$ and $1.5444 \mu \mathrm{g} \mathrm{g}^{-1}$, respectively).

Moura et al. (2018) studied $\mathrm{Hg}$ concentrations in the biota of the estuarine region of the Jaguaribe River in Ceará, and concluded that the highest concentrations in fish were found in carnivorous species, but no significant differences were found among the average concentrations between carnivorous and omnivorous fish.

This finding is consistent with earlier observations on the biota of the Amazon Basin (Dórea and Barbosa, 2007; da Silva et al., 2009). According to Dórea and Barbosa (2007) a wide variation in fish mercury bioaccumulation is expected in the complex and biologically dense environment of the Amazon rainforest.

In all species studied (Figure 3), the average concentrations were below the maximum limit of $0.5 \mu \mathrm{g} \mathrm{g}^{-1}$ of $\mathrm{Hg}$ in non-predatory fish and $1.0 \mu \mathrm{g} \mathrm{g}^{-1}$ in predatory fish established by the National Agency of Health Surveillance - ANVISA (2013). Considering each species, the minimum and maximum values of mercury in the muscle and liver tissues showed wide dispersion.

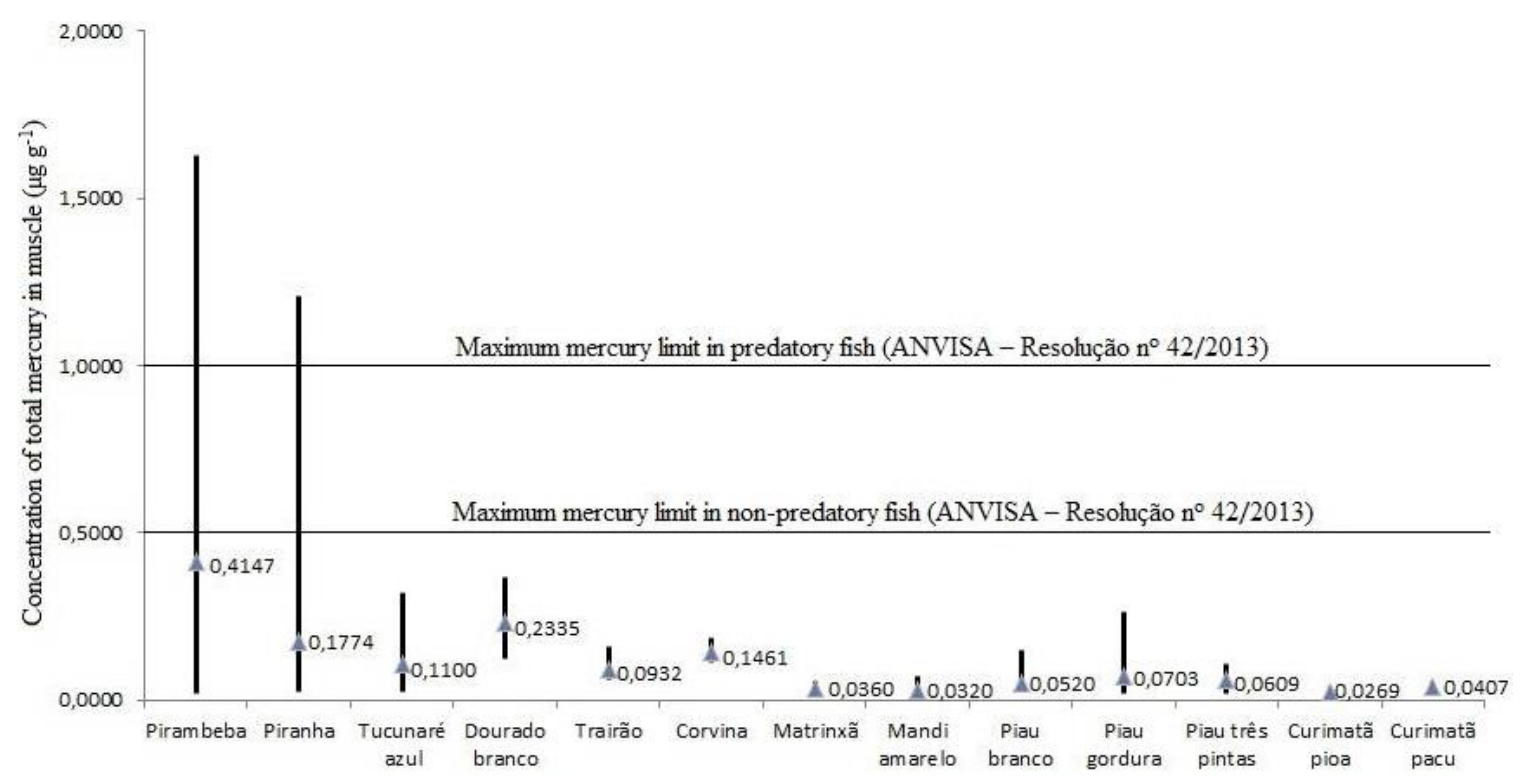

Figure 3. Average concentrations (minimum and maximum) of mercury in muscle of the fish species studied, compared to the limit established by law in Brazil. 
Table 1. Species, popular name, feeding habit, collected specimens (n), average concentrations of total mercury in muscle and liver, and biometric data (total length and body weight) of fish caught in the Três Marias Reservoir.

\begin{tabular}{|c|c|c|c|c|c|}
\hline \multirow{2}{*}{ Species / Popular name } & \multirow{2}{*}{ Eating habits / Specimens (n) } & \multicolumn{2}{|c|}{ Total mercury concentration $\left(\mu \mathrm{g} \mathrm{g}^{-1}\right)$} & \multicolumn{2}{|c|}{ Biometric data } \\
\hline & & Muscle & Liver & Total length $(\mathrm{cm})$ & Body weight (g) \\
\hline Serrasalmus brandtii & Carnivore & $0.4147 \pm 0.2744$ & $0.1872 \pm 0.2363$ & $19.2 \pm 4.7$ & $197.2 \pm 152.1$ \\
\hline Pirambeba & 178 & $(0.0206-1.6303)$ & $(0.0079-2.4335)$ & $(10.6-30.0)$ & $(24.0-716.0)$ \\
\hline Pygocentrus piraya & Carnivore & $0.1774 \pm 0.2980$ & $0.1528 \pm 0.3879$ & $32.8 \pm 6.4$ & $1.299 .1 \pm 801.1$ \\
\hline Piranha & 15 & $(0.0262-1.2073)$ & $(0.0113-1.5444)$ & $(17.0-45.5)$ & $(136.0-3.508 .0)$ \\
\hline Cichla piquiti & Carnivore & $0.1100 \pm 0.0707$ & $0.1547 \pm 0.1254$ & $27.1 \pm 8.0$ & $397.0 \pm 276.5$ \\
\hline Tucunaré azul & 37 & $(0.0230-0.3202)$ & $(0.0368-0.5033)$ & $(11.5-41.5)$ & $(19.4-1.171 .6)$ \\
\hline Salminus hilarii & Carnivore & $0.2335 \pm 0.0859$ & $0.1217 \pm 0.0451$ & $30.6 \pm 2.4$ & $294.1 \pm 72.7$ \\
\hline Dourado branco & 7 & $(0.1219-0.3680)$ & $(0.0783-0.1876)$ & $(25.5-32.5)$ & $(170.0-376.0)$ \\
\hline Holias intermedius & Carnivore & $0.0932 \pm 0.0388$ & $0.0565 \pm 0.0175$ & $36.3 \pm 7.7$ & $578.6 \pm 286.6$ \\
\hline Trairão & 5 & $(0.0623-0.1607)$ & $(0.0293-0.0718)$ & $(23.0-41.0)$ & $(130.0-889.0)$ \\
\hline Pachyurus francisci & Carnivore & $0.1461 \pm 0.0382$ & $0.1916 \pm 0.0576$ & $29.9 \pm 3.8$ & $247.9 \pm 48.5$ \\
\hline Corvina & 3 & $(0.1112-0.1869)$ & $(0.1338-0.2490)$ & $(26.0-33.5)$ & $(197.5-294.3)$ \\
\hline Brycon orthotaenia & Omnivorous & $0.0360 \pm 0.0125$ & $0.0284 \pm 0.0157$ & $28.5 \pm 6.2$ & $330.0 \pm 245.3$ \\
\hline Matrinxã & 7 & $(0.0214-0.0540)$ & $(0.0097-0.0546)$ & $(22.2-38.1)$ & $(134.0-690.0)$ \\
\hline Pimelodus maculatus & Omnivorous & $0.0320 \pm 0.0143$ & $0.0809 \pm 0.0603$ & $23.1 \pm 2.3$ & $142.9 \pm 45.7$ \\
\hline Mandi amarelo & 15 & $(0.0216-0.0741)$ & $(0.0387-0.2348)$ & $(18.9-28.3)$ & $(68.0-241.0)$ \\
\hline Leporinus piau & Omnivorous & $0.0703 \pm 0.0623$ & $0.0740 \pm 0.0684$ & $24.5 \pm 3.1$ & $314.2 \pm 142.6$ \\
\hline Piau gordura & 16 & $(0.0184-0.2611)$ & $(0.0161-0.2521)$ & $(18.0-31.0)$ & $(104.0-660.0)$ \\
\hline Leporinus reinhardti & Omnivorous & $0.0609 \pm 0.0396$ & $0.0539 \pm 0.0319$ & $22.9 \pm 2.0$ & $198.5 \pm 58.0$ \\
\hline Piau três pintas & 8 & $(0.0188-0.1062)$ & $(0.0190-0.1177)$ & $(20.4-26.0)$ & $(116.0-289.0)$ \\
\hline Prochilodus costatus & Detritivore & $0.0269 \pm 0.0114$ & $0.0595 \pm 0.0312$ & $20.2 \pm 2.3$ & $112.3 \pm 30.8$ \\
\hline Curimatã pioa & 3 & $(0.0189-0.0399)$ & $(0.0408-0.0955)$ & $(18.2-22.7)$ & $(88.0-147.0)$ \\
\hline Prochilodus argenteus & Detritivore & $0.0407 \pm 0.0127$ & $0.1735 \pm 0.1034$ & $27.5 \pm 2.2$ & $330.5 \pm 95.7$ \\
\hline Curimatã pacu & 4 & $(0.0288-0.0581)$ & $(0.1053-0.3275)$ & $(24.4-29.5)$ & $(199.0-415.0)$ \\
\hline Schizodon knerii & Herbivore & $0.0520 \pm 0.0391$ & $0.0651 \pm 0.0512$ & $31.0 \pm 8.1$ & $590.2 \pm 465.1$ \\
\hline Piau branco & 13 & $(0.0227-0.1501)$ & $(0.0263-0.2099)$ & $(20.0-42.0)$ & $(120.0-1.392 .0)$ \\
\hline
\end{tabular}


There was a strong highly significant positive correlation (Table 2) between the concentrations of mercury in the muscle and in the liver of the Piranha $(\mathrm{r}=0.9770$ and $\mathrm{P}$ $<0.0001)$, of the Mandi amarelo $(\mathrm{r}=0.8834$ and $\mathrm{P}<0.0001)$, Pirambeba $(\mathrm{r}=0.7177$ and $\mathrm{P}$ $<0.0001)$ and Tucunaré azul $(\mathrm{r}=0.6888$ and $\mathrm{P}<0.0001)$; between muscle concentrations and the total length of the Tucunaré azul $(\mathrm{r}=0.7279$ and $\mathrm{P}<0.0001)$; between muscle concentrations and body weight of Piranha ( $\mathrm{r}=0.7154$ and $\mathrm{P}<0.0027)$, Piau branco $(\mathrm{r}=0.7883$ and $\mathrm{P}<0.0014)$ and Tucunaré azul $(\mathrm{r}=0,6500$ and $\mathrm{P}<0.0001)$; between liver concentrations and body weight of Piranha $(\mathrm{r}=0.7487$ and $\mathrm{P}<0.0013)$; and between the total length and the body weight of all species.

Table 2. Species, popular name, eating habits, collected specimens (n), mean concentrations of total mercury in muscle and liver, and biometric data (total length and body weight) of fish caught in the Três Marias Reservoir.

\begin{tabular}{lcccccc}
\hline \multirow{2}{*}{$\begin{array}{c}\text { Popular name / } \\
\text { Eating habits }\end{array}$} & \multicolumn{5}{c}{ r $($ Person $) /(\mathrm{P})$} \\
\cline { 2 - 7 } & Hg-M e HgF & Hg-M e CT & Hg-M e PC & Hg-F e CT & Hg-F e PC & CT e PC \\
\hline Pirambeba & $\mathbf{0 . 7 1 7}$ & 0.3374 & 0.2893 & 0.1557 & 0.1554 & $\mathbf{0 . 9 4 3 2}$ \\
Carnivore & $<\mathbf{0 . 0 0 0 1}$ & $<0.0001$ & 0.0001 & 0.0385 & 0.0389 & $<\mathbf{0 . 0 0 0 1}$ \\
Piranha & $\mathbf{0 . 9 7 7}$ & 0.5095 & $\mathbf{0 . 7 1 5 4}$ & 0.5379 & $\mathbf{0 . 7 4 8 7}$ & $\mathbf{0 . 9 2 5 4}$ \\
Carnivore & $<\mathbf{0 . 0 0 0 1}$ & 0.0523 & $\mathbf{0 . 0 0 2 7}$ & 0.0386 & $\mathbf{0 . 0 0 1 3}$ & $<\mathbf{0 . 0 0 0 1}$ \\
Tucunaráy azul & $\mathbf{0 . 6 8 8 5}$ & $\mathbf{0 . 7 2 7 9}$ & $\mathbf{0 . 6 5 0 0}$ & 0.5563 & 0.5491 & $\mathbf{0 . 9 4 4 4}$ \\
Carnivore & $\mathbf{0 . 0 0 0 1}$ & $\mathbf{0 . 0 0 0 1}$ & $<\mathbf{0 . 0 0 0 1}$ & 0.0003 & 0.0004 & $<\mathbf{0 . 0 0 0 1}$ \\
Mundi amarelo & $\mathbf{0 . 8 8 3 4}$ & 0.5034 & 0.4491 & 0.5830 & 0.5093 & $\mathbf{0 . 9 2 9 2}$ \\
Omnivorous & $\mathbf{0 . 0 0 0 1}$ & 0.0557 & 0.0930 & 0.0225 & 0.0524 & $<\mathbf{0 . 0 0 0 1}$ \\
Piau gordura & 0.3703 & -0.2745 & -0.2971 & -0.2241 & -0.3836 & $\mathbf{0 . 9 2 3 3}$ \\
Omnivorous & 0.1579 & 0.3035 & 0.2638 & 0.4040 & 0.1423 & $<\mathbf{0 . 0 0 0 1}$ \\
Piau branco & 0.3448 & 0.6955 & $\mathbf{0 . 7 8 8 3}$ & 0.3566 & 0.4749 & $\mathbf{0 . 9 5 3 1}$ \\
Herbivore & 0.2485 & 0.0083 & $\mathbf{0 . 0 0 1 4}$ & 0.2316 & 0.1009 & $<\mathbf{0 . 0 0 0 1}$ \\
\hline
\end{tabular}

Teodoro (2007) studied mercury concentration levels in fish belonging to different trophic levels of the Pantanal Sul Mato Grosso, and found that the piscivores presented mercury concentrations in muscle tissue higher than omnivores, detritivores and herbivores, and no significant correlation was observed between these concentrations and biometric data. Azevedo (2016) observed significant correlations between biometric variables and mercury concentrations in pimelodus fur muscle $(r=0.38, \mathrm{P}<0.05)$ captured in the Paraíba do Sul River.

Cardoso et al. (2009) determined the mercury (Hg) contents in organs of the carnivorous species Trichiurus lepturus (swordfish) commercialized in the Itaipu Beach region, Niterói $\mathrm{RJ}$, and identified a highly significant correlation between hg contents in musculature with total length $(\mathrm{r}=0.85$ and $\mathrm{P}<0.0001)$ and total weight $(\mathrm{r}=0.88$ and $\mathrm{P}<0.0001)$.

Seven specimens of Pirambeba $(4 \%)$ and one of Piranha $(7 \%)$ exceeded the maximum limit of $1.0 \mu \mathrm{g} \mathrm{g}^{-1} \mathrm{Hg}$ in predatory fish, established by ANVISA, and, therefore, were considered unfit for human consumption. The other species did not present muscle samples with $\mathrm{Hg}$ content above the one established by law. In 94\% of the specimens collected from Pirambeba (167), muscle tissue accumulated from 1.02 to 8.09 times more mercury than liver tissue. The same occurred with $87 \%$ of the specimens collected from the Piranha (Mason et al., 1995), where muscle tissue accumulated from 1.30 to 3.44 times more mercury than liver tissue.

The F (regression) values were significant (Figure 4) for the species: Piranha $(\mathrm{P}<0.0001$ and $\left.\mathrm{R}^{2}=0.9546\right)$, Yellow mandi $\left(\mathrm{P}<0.0001\right.$ and $\left.\mathrm{R}^{2}=0.7804\right)$, Pirambeba $\left(\mathrm{P}<0.0001\right.$ and $\mathrm{R}^{2}$ $=0.5065)$ and Blue peacock bass $\left(P<0.0001\right.$ and $\left.R^{2}=0.4740\right)$, where the total $\mathrm{Hg}$ concentration in muscle increases as it does in the liver. The comparative analysis of regression coefficients showed non-significant $F$ (regression) values for the species Piau gordura $(\mathrm{P}=0.1552)$ and Piau branco $(\mathrm{P}=0.2476)$. 

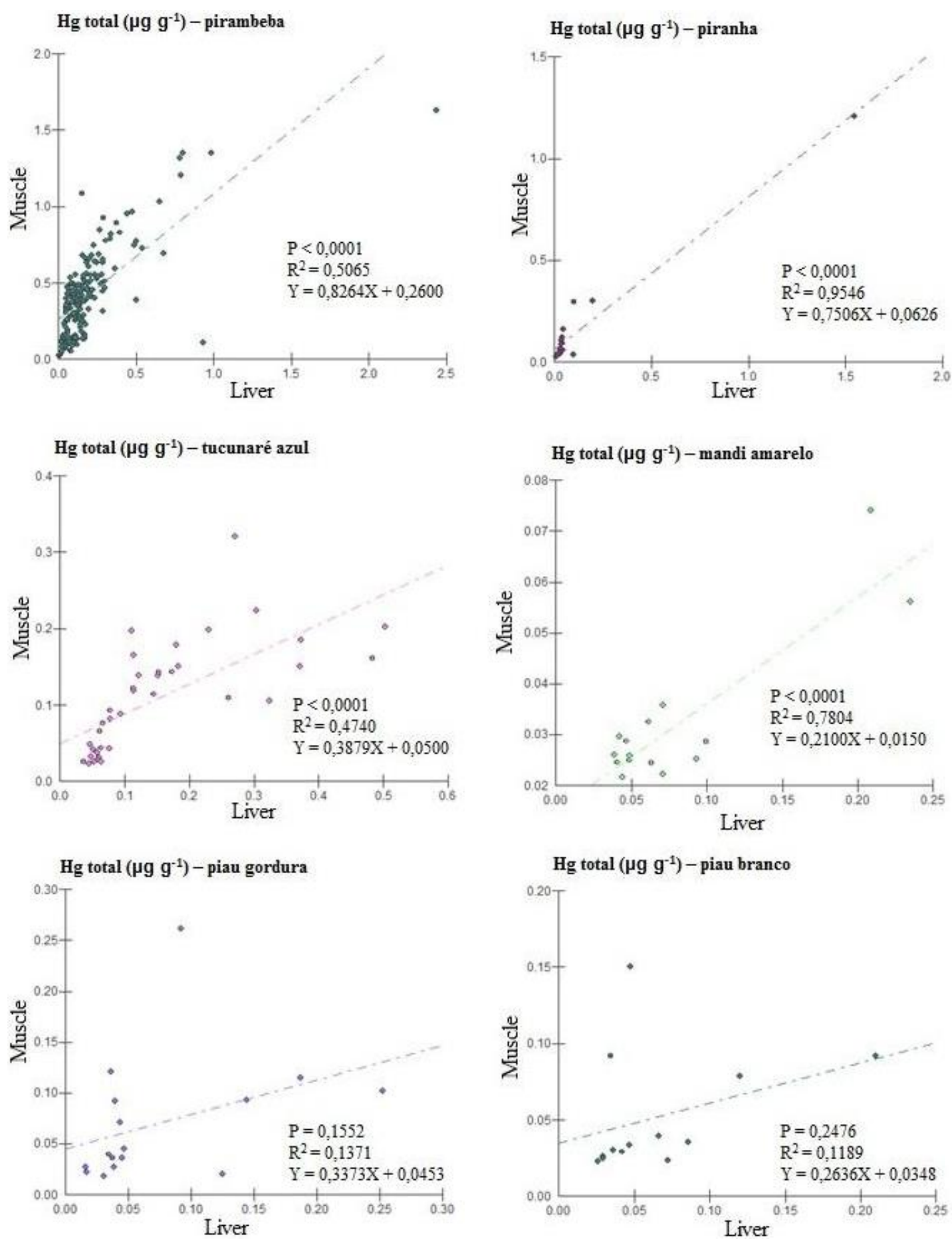

Figure 4. Probability $(\mathrm{P})$ and coefficient of determination $\left(\mathrm{R}^{2}\right)$ of simple linear regressions for total mercury concentration $\left(\mu \mathrm{g} \mathrm{g}^{-1}\right)$ in muscle in relation to fish.

The consumption of fish contaminated with mercury can result in the ingestion of high levels of methylmercury, since, due to biomagnification, this corresponds to approximately $100 \%$ of all mercury which is bioaccumulated in the tissues of predators (USEPA, 2001). As preventive measures, the World Health Organization suggests that in populations which consume large amounts of fish (e.g., $100 \mathrm{~g}$ per day), capillary levels of methylmercury in women of childbearing age should be monitored. If the results of these monitoring activities indicate excessive exposure to $\mathrm{MeHg}$, appropriate measures should be taken to reduce the possibility of prolonged exposure during pregnancy and keep it below the internationally permitted consumption number, including reduced fish consumption (WHO, 1990). 
Some studies suggest several intervention measures with the participation of communities affected by the presence of mercury, including maintaining fish consumption while giving preference to non-carnivores, thus reducing mercury levels in the population (Mergler, 2002; Mertens et al., 2005).

\section{CONCLUSION}

Of all the species analyzed, Serrasalmus brandtii (pirambeba) $(\mathrm{n}=178)$ and Pygocentrus piraya (piranha) $(\mathrm{n}=15)$ presented the highest concentrations of total mercury in muscle tissue. Evaluating the risks of the consumption of fish contaminated with mercury, it was found that $4 \%$ of the Pirambeba and 7\% of Piranha specimens exceeded the limit of $1.0 \mu \mathrm{g} \mathrm{g}^{-1} \mathrm{hg}$ in predatory fish, established by the National Health Surveillance Agency, thus being unsuitable for human consumption. Due to its carnivorous eating habits and its wide distribution in the São Francisco River Basin, Serrasalmus brandtii can be considered as a biomonitor, capable of bioaccumulating mercury, thus indicating the level of contamination of this metal in the aquatic environment in which it lives. The other species did not present muscle samples with $\mathrm{Hg}$ content above that established by law.

The increase in mercury levels in the waters of the Paraopeba River may cause bioaccumulation of this metal in fish of the entire trophic chain, and thus pose a risk to the population in the medium and long term. Thus, it is suggested that new studies of the temporal variation of these levels be conducted, comparing them with the levels presented in this study prior to the rupture of the Brumadinho Dam.

\section{ACKNOWLEDGEMENT}

To the Postdoctoral Program of the Federal University of Sergipe - UFS, to the São Francisco and Parnaíba Valley Development Company - CODEVASF, and to the Superintendence of the Brazilian Institute of the Environment and Renewable Natural Resources (IBAMA) in Minas Gerais.

\section{REFERENCES}

ANVISA (Brasil). Resolução no 42, de 29 de agosto de 2013. Dispõe sobre o Regulamento Técnico MERCOSUL sobre Limites Máximos de Contaminantes Inorgânicos em Alimentos. República Federativa do Brasil, Diário Oficial [da] União, Brasília, DF, seção 1, n. 168, p. 33, 30 ago. 2013.

ASSIS, E. M. de et al. High concentrations of toxic metals in water consumed by the Maxakali indigenous community in Brazil. Revista Ambiente \& Água, v. 14, n. 1, p. 1-17, 2019. http://dx.doi.org/10.4136/ambi-agua.2215

AZEVEDO, L. S. Bioacumulação de mercúrio em espécies ícticas na porção inferior do rio Paraíba do Sul. 2016. 35f. Dissertação (Mestrado em Ecologia e Recursos Naturais) Universidade Estadual do Norte Fluminense Darcy Ribeiro, Campos dos Goytacazes, 2016.

BAHIA, M. O. Le potentiel génotoxique du mercure: mutations HPRTet effects cytogénétiques. 1997. 119f. Dissertação (Mestrado) - Université du Quebéc à Montreal, Montreal, 1997. 119 p.

BARRAGÁN, B. L. G. et al. Presence of pesticides, mercury and trihalomethanes in the water supply systems of Ibagué, Colombia: threats to human health. Revista Ambiente \& Água, v. 15, n. 2, p. 1-11, 2020. http://dx.doi.org/10.4136/ambi-agua.2477 
BARROCAS, P.R.; WASSERMAN, J. C. O mercúrio na baía de Guanabara; uma visão histórica. Geochimica Brasiliensis, v. 9, n. 2, p. 115-127, 1995. https://dx.doi.org/10.21715/gb.v9i2.86

BARRON, M. G. Bioaccumulation and Bioconcentration in Aquatic Organisms. In: HOFFMAN, D. J.; RATTNER, B. A.; BURTON JR, G. A.; CAIRNS JR., J. (eds.). Handbook of ecotoxicology. 2. ed. Boca Raton: Lewis Publishers, 2003. Chapter 32, p. 878-892.

BASTOS, W. R.; GOMES, J. P. O.; OLIVEIRA, R. C.; ALMEIDA, R.; NASCIMENTO, E. L.; BERNARDI, J. V. E.; de LACERDA, L. D.; da SILVEIRA, E. G.; PFEIFFER, W. C. Mercury in the environment and riverside population in the Madeira River Basin, Amazon, Brazil. Science of the Total Environment, v. 368, n. 1, p. 344-351, 2006. http://dx.doi.org/10.1016/j.scitotenv.2005.09.048

BOENING, D. W. Ecological Effects, Transport, and Fate of Mercury: a general review. Chemosphere, v. 40, n. 12, p. 1335-1351, 2000. http://dx.doi.org/10.1016/S00456535(99)00283-0

BRITSKI, H. A.; SATO, Y.; ROSA, A. B. S. Manual de identificação de peixes da região de Três Marias: com chaves de identificação para os peixes da bacia do São Francisco. 3. ed. Brasília: Câmara dos Deputados/Codevasf, 1988. 115 p.

CARDOSO, T. P.; MÁRSICO, E. T.; MEDEIROS, R. J.; TORTELLY, R.; SOBREIRO, L. G. Concentração de mercúrio e análise histopatológica em músculo, rim e cérebro de peixeespada (Trichiurus lepturus) coletados na praia de Itaipu, Niterói, Rio de Janeiro, Brasil. Ciência Rural, v. 39, n. 2, p. 540-546, 2009. http://dx.doi.org/10.1590/S010384782008005000062

CLARKSON, T. W. Human toxicology of mercury. The Journal of Trace Elements in $\begin{array}{lllllll}\text { Experimental Medicine, v. 11, n. 23, p. 303-317, } 1998 . & \text { v. }\end{array}$ http://dx.doi.org/10.1002/(SICI)1520-670X(1998)11:2/3<303::AID-JTRA18>3.0.CO;2-V

COSTA JR., J. M. F.; LIMA, A. A. S.; RODRIGUES Jr., D; SILVA, M. C. F.; SOUZA, G. S.; SILVEIRA, L. C. L.; PINHEIRO, M. C. N. Avaliação dos níveis de exposição ao mercúrio em comunidades ribeirinhas da região do Tapajós, no período de 2012-2014. Pesquisa em Saúde, v. 14, p. 29-34, 2015.

COSTA JR., J. M. F.; SILVA, C. I. M.; LIMA, A. A. S.; RODRIGUES JÚNIOR, D.; SILVEIRA, L. C. L.; SOUZA, G. S.; PINHEIRO, M. C. N. Teores de mercúrio em cabelo e consumo de pescado de comunidades ribeirinhas na Amazônia brasileira, região do Tapajós. Ciência \& Saúde Coletiva, v. 23, n. 3, p. 805-812, 2018. http://dx.doi.org/10.1590/1413-81232018233.09492016

DIETZ, R.; RIGET, F.; CLEEMANN, M.; AARKROG, A.; JOHANSEN, P.; HANSEN, J. C. Comparison of contaminants from different trophic levels and ecosystems. Science of the Total Environment, v. 245, n. 1-3, p. 221-231, 2000. http://dx.doi.org/10.1016/S00489697(99)00447-7

DOREA, J. G.; BARBOSA, A. C.; SILVA, G. S. Fish mercury bioaccumulation as a function of eating behavior and hydrological cycles of the Rio Negro, Amazon. Comparative Biochemistry and Physiology Part C: Toxicology \& Pharmacology, v. 142, n. 3-4, p. 275-283, 2006. http://dx.doi.org/10.1016/j.cbpc.2005.10.014

DÓREA, J. G.; BARBOSA, A. C. Anthropogenic impact of mercury accumulation in fish from the Rio Madeira and Rio Negro rivers (Amazonia). Biological Trace Element Research, v. 115, p. 243-254, 2007. https://doi.org/10.1007/BF02685999 
FISHBASE. Fishbase. Available at: https://www.fishbase.in/search.php. Access: 03 Apr. 2019.

FÖRSTNER, U. E.; WITTMAnN, G. T. W. Metal Pollution in the Aquatic Environment. 2. ed. New York: Springer-Verlag, 1983. 485 p. http://dx.doi.org/10.1007/BF02857454

GILMOUR, C. C.; HENRY, E. A. Mercury methylation in aquatic systems affected by acid deposition. Environmental Pollution, v. 71, n. 2-4, p. 131-169, 1991. http://dx.doi.org/10.1016/0269-7491(91)90031-q

GILMOUR, C. C.; RIEDEL, G. S. A Survey of Size-Specific Mercury Concentrations in Game Fish from Maryland Fresh and Estuarine Waters. Archives of Environmental

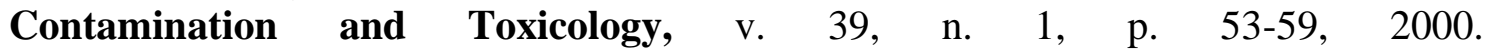
http://dx.doi.org/10.1007/s002440010079

HECKY, R. E.; RAMSEY, D. J.; BODALY, R. A.; STRANGE, N. E. Increased methylmercury contamination in fish in newly formed freshwater reservoirs. In: SUZUKI, T.; IMURA, N.; CLARKSON, T. W. (eds.). Advances in Mercury Toxicology. New York: Plenum Press, 1991. p. 33-52. http://dx.doi.org/10.1007/978-1-4757-9071-9_2

HINA, N.; RIAZ, R.; ALI, U.; RAFIQUE, U.; MALIK, R. N. A Quantitative Assessment and Biomagnification of Mercury and Its Associated Health Risks from Fish Consumption in Freshwater Lakes of Azad Kashmir, Pakistan. Biological Trace Element Research, 2021. https://doi.org/10.1007/s12011-020-02479-z

LEE, R.; MIDDLETON, D.; CALDWELL, K.; DEARWENT, S.; JONES, S.; LEWIS, B.; MONTEILH, C.; MORTENSEN, M. E.; NICKLE, R.; ORLOFF, K.; REGER, M.; RISHER, J.; SCHURZ ROGERS, H.; WATTERS, M. A review of events that expose children to elemental mercury in the United States. Ciência e Saúde Coletiva, v. 15, n. 2, p. 585-598, 2010. http://dx.doi.org/10.1590/S1413-81232010000200035

LIMA, A. C. M.; OLIVEIRA, C. S. B.; XAVIER, C. T. S.; PINHEIRO, M. C. N.; SOUZA, D. M.; MAGALHÃES, C. M. C.; PINTO, R. F. Exposição ao mercúrio em escolares de áreas ribeirinhas na Amazônia brasileira. Revista de Pesquisa em Saúde, v. 14, p. 1421, 2015.

MASON, R. P.; REINFELDER Jr.; MOREL, F. M. M. Bioaccumulation of mercury and methylmercury. Water, Air, Soil Pollution, v. 80, p. 915-921, 1995. http://dx.doi.org/10.1007/BF01189744

MERGLER, D. Review of neurobehavioral deficits and river fish consumption from the Tapajós's (Brazil) and St. Lawrence (Canada). Environmental Toxicology and Pharmacology, v. 12, n. 2, p. 93-99, 2002. http://dx.doi.org/10.1016/s13826689(02)00027-3

MERTENS, F.; SAINT-CHARLES, J.; MERGLER, D.; PASSOS, C. J.; LUCOTTE, M. A network approach for analysing and promoting equity in participatory ecohealth research. EcoHealth, v. 2, n. 2, p. 113-126, 2005. https://dx.doi.org/10.1007/s10393-004-0162-y

MIRANDA, M. R.; COELHO-SOUZA, A. S.; GUIMARÃES, J. R. D.; CORREIA, R. R. S.; OLIVEIRA, D. Mercúrio em sistemas aquáticos: fatores ambientais que afetam a metilação. Oecology Brasiliensis, v. 11, n. 2, p. 240-251, 2007.

MOURA, V. L.; COSTA, B. G. B.; LACERDA, L. D. Distribuição de mercúrio na fauna estuarina do rio Jaguaribe - CE. Arquivos de Ciências do Mar, v. 51, n. 1, p. 49-56, 2018. https://dx.doi.org/10.32360/acmar.v51i1.32972 
NEUMANN, R. M.; WARD, S. M. Bioaccumulation and Biomagnification of Mercury in Two Warmwater Fish Communities. Journal of Freshwater Ecology, v. 14, n. 4, p. 487-498, 1999. https://dx.doi.org/10.1080/02705060.1999.9663707

PINHEIRO, M. C. N.; OIKAWA, T.; VIEIRA, J. L. F.; GOMES, M. S. V.; GUIMARÃES, G. D. A.; CRESPO-LÓPEZ, M. E.; MULLER, R. C. S.; AMORAS, W. W.; RIBEIRO, D. R. G.; RODRIGUES, A. R.; CÔRTES, M. I. T.; SILVEIRA, L. C. L. Comparative study of human exposure to mercury in riverside communities in the Amazon region. Brazilian Journal of Medical and Biological Research, v. 39, n. 3, p. 411-414, 2006, https://dx.doi.org/10.1590/S0100-879X2006000300012

SCHETAGNE, R.; THERRIEN, J. Environmental Monitoring at the La Grande Complex. Evolution of Fish Mercury Levels. Summary Report 1978-2012. Quebec: Genivar Inc. and Hydro-Québec Production, 2013. 172 p.

SILVA, C. A. D.; SANTOS, S. D. O.; GARCIA, C. A. B.; DE PONTES, G. C.; WASSERMAN, J. C. Metals and arsenic in marine fish commercialized in the NE Brazil: Risk to human health. Human and Ecological Risk Assessment: An International Journal, v. 26, n. 3, p. 695-712, 2020.

SILVA, M. W.; ESTANISLAU, C. A. M. Concentração de mercúrio em peixes da Amazônia. Boletim ABLimno, v. 41, n. 1, p. 08-14, 2015.

SILVA, D. S.; LUCOTTE, M.; PAQUET, S.; DAVIDSON, R. Influence of ecological factors and of land use on mercury levels in fish in the Tapajós River basin, Amazon. $\begin{array}{llllll}\text { Environmental Research, } & \text { v. 4, 4. 432-46, }\end{array}$ https://dx.doi.org/10.1016/j.envres.2009.02.011

SILVA OLIVEIRA, C. A.; KASPER, D.; SARGENTINI JUNIOR, É.; BOLSON, M. A.; TORREZANI, L.; ZARA, L. F. Influence of environmental conditions on the mercury levels of the sediment along the Balbina Reservoir, Brazilian Amazon. Environmental Monitoring Assessment, v. 193, n. 50, 2021. https://doi.org/10.1007/s10661-02008837-7

STERLING, T. M. Mechanisms of herbicide absorption across plant membranes and accumulation in plant cells. Weed Science, v. 42, n. 2, p. 263-276, 1994. https://dx.di.org/10.1017/S0043174500080383

TEODORO, E. M. Determinação de mercúrio em cérebro e músculo de peixes do pantanal sul via CV-AAS. 2007. 56f. Dissertação (Mestrado) - Universidade de Brasília, Brasília, $2007.56 \mathrm{p}$.

TRASANDE, L.; CORTES, J. E.; LANDRIGAN, P. J.; ABERCROMBIE, M. I.; BOPP, R. F.; CIFUENTES, E. Methylmercury exposure in a subsistence fishing community in Lake Chapala, Mexico: an ecological approach. Environ Health, v. 9, n. 1, p. 1-10, 2010. https://dx.doi.org/10.1186/1476-069X-9-1

TRASANDE, L.; LANDRIGAN, P. J.; SCHECHTER, C. Public health and economic consequences of methyl mercury toxicity to the developing brain. Environmental Health Perspectives, v. 113, n. 5, p. 590-596, 2005. https://dx.doi.org/10.1289/ehp.7743

USEPA. Method 7473 (SW-846), Mercury in Solids and Solutions by Thermal Decomposition, Amalgamation, and Atomic Absorption Spectrophotometry. Washington, 2007. 
USEPA. Water Quality Criterion for the Protection of Human Health: Methylmercury. EPA-823-R-01-001. Washington, 2001.

WHO. Guidance for identifying populations at risk from mercury exposure. Geneva, 2008. $170 \mathrm{p}$.

WHO. International Programme on Chemical Safety. IPCS Environmental Health Criteria 101: Methylmercury. Geneva, 1990. 143 p.

ZAMPIERI, B. D. B.; da COSTA ANDRADE, V.; CHINELLATO, R. M.; GARCIA, C. A. B.; de OLIVEIRA, M. A.; BRUCH, G.; de OLIVEIRA, A. J. F. C. Heavy metal concentrations in Brazilian port areas and their relationships with microorganisms: can pollution in these areas change the microbial community. Environmental Monitoring Assessment, v. 192, p. 512, 2020. https://doi.org/10.1007/s10661-020-08413-z 